\title{
Managing Southern Chinch Bug in Warm Season Turfgrasses ${ }^{1}$
}

\author{
Eileen A. Buss, Brianna M. Whitman, and Adam G. Dale²
}

\section{Introduction}

Southern chinch bug, Blissus insularis Barber (http://edis. ifas.ufl.edu/IN383), is the most damaging insect pest of St. Augustinegrass, Stenotaphrum secundatum (Walt.) Kuntze (http://edis.ifas.ufl.edu/lh010) in the United States. St. Augustinegrass is a warm season turfgrass commonly used in lawns throughout the southern United States. In fact, St. Augustinegrass is the most common turfgrass in Florida and in 2007 comprised $51 \%$ of total sod acreage in the state (Satterthwaite et al. 2009). Although southern chinch bugs are primarily pests of St. Augustinegrass, the widespread use of this turfgrass species makes southern chinch bug an economically important pest. Making insecticide applications to control this pest and paying for turfgrass replacement after chinch bug damage cost Florida homeowners and professionals millions of dollars annually. Therefore, it is important for homeowners and pest management professionals to be familiar with southern chinch bug biology, damage, and management.

\section{Biology}

The southern chinch bug undergoes incomplete metamorphosis, which means it has three life stages: egg, nymph, and adult. A single female will produce up to 300 eggs in her lifetime and average between four and five per day depending on host plant and environmental conditions. Eggs are about $1 \mathrm{~mm}$ long, oblong, and deposited singly in the thatch layer, within the leaf sheath, or on leaf surfaces. They are initially white or cream colored and gradually turn orange as they develop. Nymphs resemble the adult but are a different color, smaller, and do not have wings. Chinch bug nymphs are initially bright red or orange with a white stripe on the abdomen (Figure 1). As nymphs molt through four distinct instars, their bodies darken and they develop wings (Figure 2). Adults are about 0.2 inches $(4.7 \mathrm{~mm})$ long and exhibit two distinct winged forms: brachypterous (short, reduced wings) and macropterous (long, full-length wings) (Figure 3).

Because insects are ectothermic, their metabolism and development speed up as temperatures warm. Thus, southern chinch bugs develop more rapidly during summer months when temperatures are higher. A nymph will emerge from the egg after 8 to 25 days, and nymphs take approximately 34 to 94 days to develop to adults ( 4 to 13 weeks combined). Adults live 42 to 100 days, and females generally live 25 to 55 days longer than the males. In northern Florida, where it is cooler, southern chinch bugs are active from approximately March to October and have

1. This document is ENY-325, one of a series of the Department of Entomology and Nematology, UF/IFAS Extension. Original publication date October 1993. Revised August 2010 and June 2018. Visit the EDIS website at http://edis.ifas.ufl.edu.

2. Eileen A. Buss, emeritus associate professor; Brianna M. Whitman, graduate student; and Adam G. Dale assistant professor and Extension specialist, Department of Entomology and Nematology; UF/IFAS Extension, Gainesville, FL 32611.

The use of trade names in this publication is solely for the purpose of providing specific information. UF/IFAS does not guarantee or warranty the products named, and references to them in this publication do not signify our approval to the exclusion of other products of suitable composition. All chemicals should be used in accordance with directions on the manufacturer's label. Use pesticides safely. Read and follow directions on the manufacturer's label.

The Institute of Food and Agricultural Sciences (IFAS) is an Equal Opportunity Institution authorized to provide research, educational information and other services

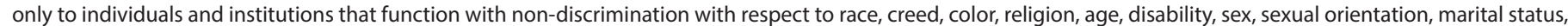

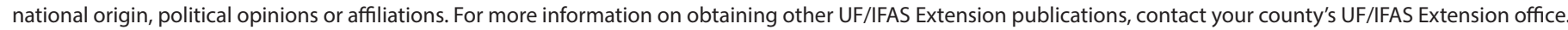
U.S. Department of Agriculture, UF/IFAS Extension Service, University of Florida, IFAS, Florida A \& M University Cooperative Extension Program, and Boards of County Commissioners Cooperating. Nick T. Place, dean for UF/IFAS Extension. 


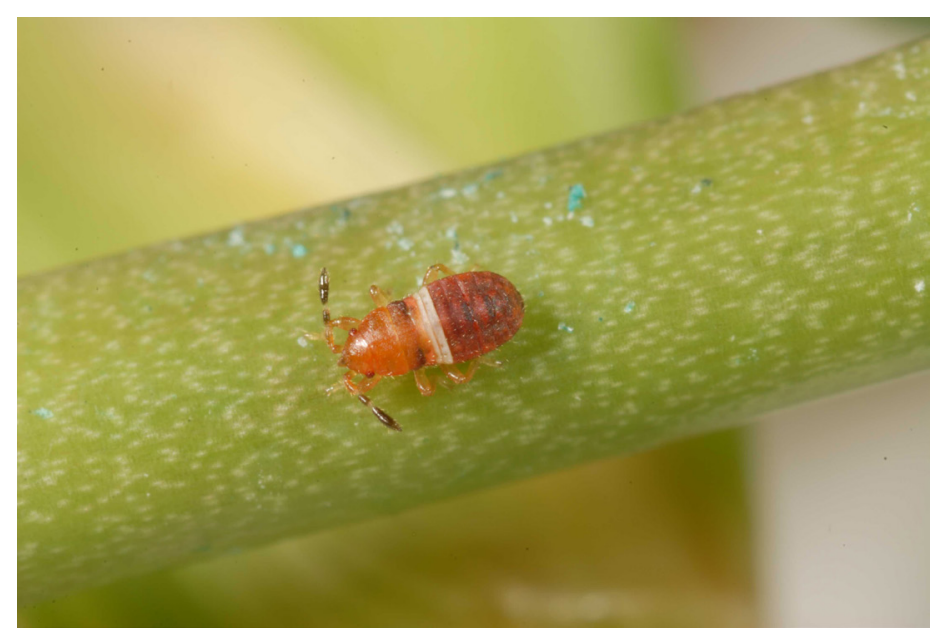

Figure 1. Young southern chinch bug nymphs are bright orange or red with a horizontal white stripe across the abdomen.

Credits: Lyle Buss, UF/IFAS Department of Entomology and Nematology

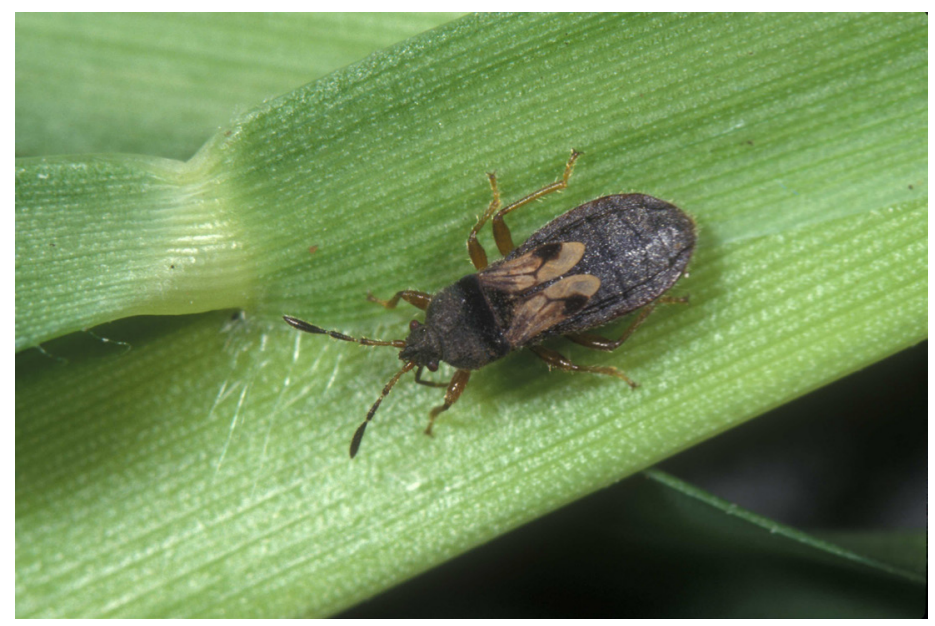

Figure 2. As southern chinch bugs develop, they darken and develop wings. Some, like the one pictured here, develop into short-winged adults.

Credits: Lyle Buss, UF/IFAS Department of Entomology and Nematology

3 to 4 generations per year. In southern Florida, there are approximately 7 to 10 generations per year (Kerr 1966).

\section{Damage}

Southern chinch bugs can rapidly damage a lawn and cause widespread plant death. Early damage appears as patchy areas of yellowing grass that rapidly browns and dies if the pest is left uncontrolled (Figure 4). The turf may initially appear to be drought stressed, which is a common misdiagnosis and allows damage to progress, often beyond repair. These patchily damaged areas are generally circular in shape and expand outward as the insects move from dying grass into healthier grass. Turf in open sunny areas or under drought stress is often the first attacked and most severely damaged by southern chinch bug. Periods of drought are often associated with elevated chinch bug abundance and

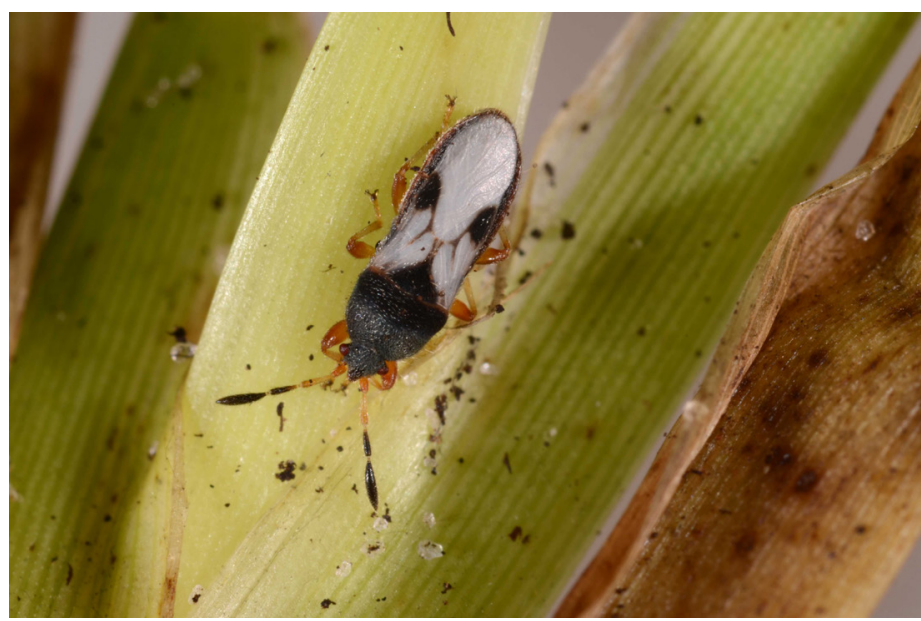

Figure 3. Adults southern chinch bugs are dark with white and black wings. They have orange legs and black-tipped antennae. Credits: Lyle Buss, UF/IFAS Department of Entomology and Nematology

damage, but this may be a result of reduced plant defense rather than increased chinch bug performance (Vasquez and Buss 2006). This pest also prefers areas that have thick thatch layers because the thatch provides the insect with a place to feed and seek refuge from natural enemies and environmental conditions.

\section{Scouting and Monitoring}

To effectively manage any pest, one must actively monitor plant material to track pest activity, abundance, and susceptibility to control measures. Southern chinch bugs live in groups or aggregations, which can facilitate detecting infestations (Addesso et al. 2012). Although adults can fly, they preferentially walk from plant to plant, which also makes them easier to detect. Individuals are typically found within the thatch layer, but when populations are high, they may be found resting on leaf blades or crawling across the lawn. Although chinch bugs are small, there are a few easy methods for detecting them in a lawn.

Southern chinch bugs are most active on warm, sunny days in mid-afternoon. The easiest method for detection is to part the grass adjacent to dead or dying regions and search the thatch, undersides of grass stolons (horizontal-growing, rooting-generating stem), and the soil surface. Remove individual grass plants and examine the areas concealed by the leaf sheath by peeling apart the plant. One can also remove a section of grass and thrash it against a white surface, such as piece of paper, to easily locate and count the insects. Examine several different areas if chinch bugs are not immediately evident.

Two other methods that require tools can also effectively identify southern chinch bug infestations. A hand-held 


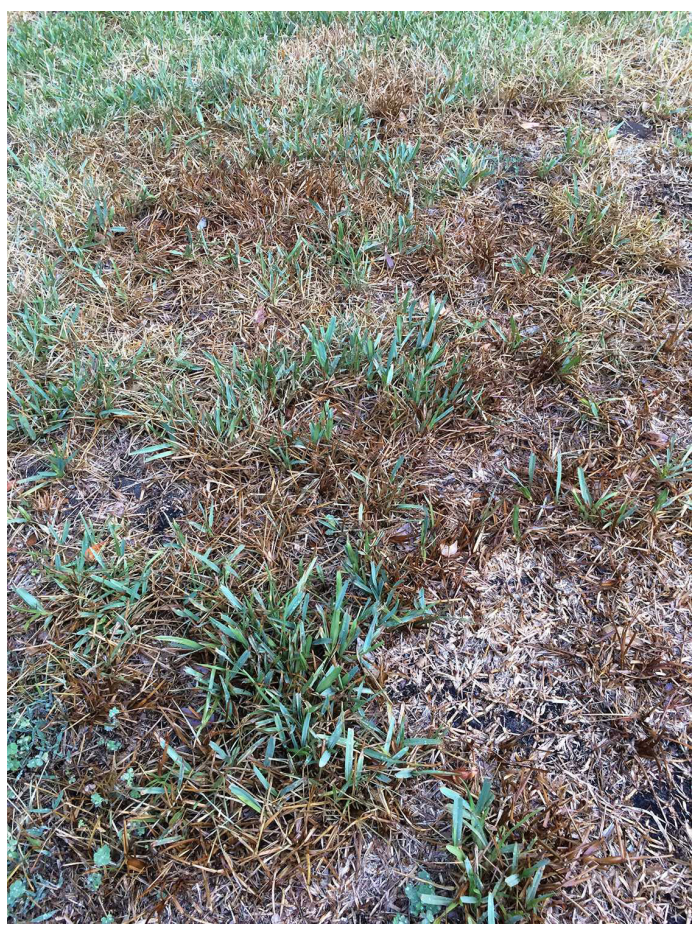

Figure 4. St. Augustinegrass heavily infested with southern chinch bug will initially turn yellow but rapidly progress to dark brown. The grass will die if the pest is not controlled.

Credits: Adam Dale, UF/IFAS Department of Entomology and Nematology

vacuum cleaner or leaf blower with the airflow reversed can be used to suck up any insects inhabiting grass within or near damaged areas (Figure 5). Leaf blower vacuums should have a mesh bag inserted and affixed to the end to capture any arthropods or plant material sucked up. Periodically remove the filter or bag, and empty the contents onto a light-colored surface, bucket, or plastic bag and search for individual insects. Repeat this in several areas of suspected infestations.

A flotation technique can also effectively detect infestations. This method requires using a metal or impermeable cylinder open on both ends (like an open-ended coffee can). Push one end 2-3 inches into the soil within green or yellowing patches of grass next to damaged areas. Slowly fill the cylinder with water and count the number of chinch bugs that float to the surface within 5 minutes. Continuously pour water into the cylinder to keep it above the grass surface. If no chinch bugs emerge in the first area, examine 3 to 4 other areas.

\section{Decision Making}

Once a southern chinch bug infestation has been identified, decide if the insect is abundant enough to warrant control efforts. Turfgrasses can typically withstand low to moderate infestations of southern chinch bug. In fact, it is estimated

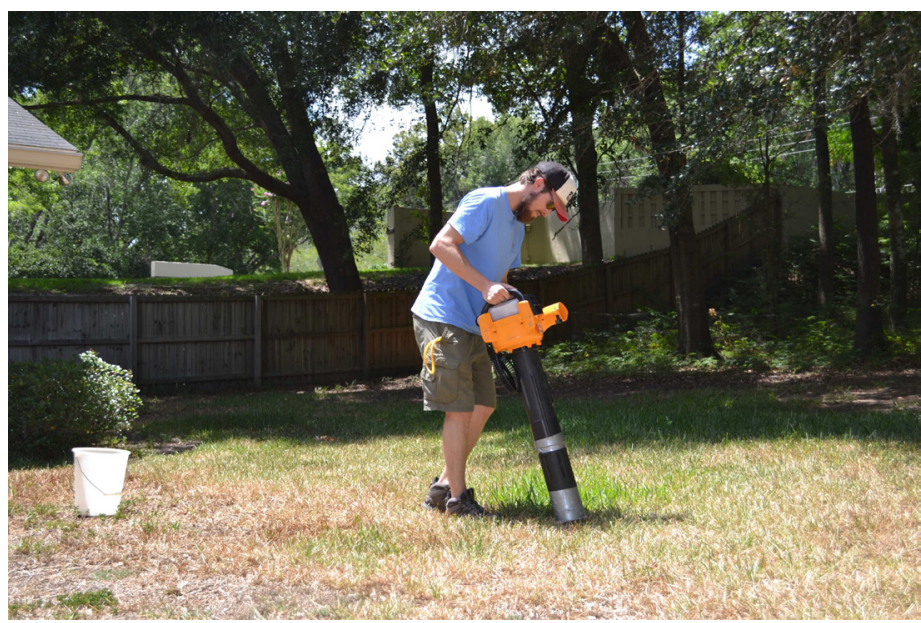

Figure 5. A hand-held vacuum or a leaf blower with the airflow reversed and a mesh bag inserted into the tube (shown above) can be used to extract southern chinch bugs from infested turfgrass. Credits: Adam Dale, UF/IFAS Department of Entomology and Nematology

that about $1 / 3$ of St. Augustinegrass lawns contain southern chinch bugs, but it is only necessary to treat when numbers reach the abundance threshold. Typically, 20 to 25 southern chinch bugs per $1 \mathrm{ft}^{2}\left(0.1 \mathrm{~m}^{2}\right)$ is enough to warrant an insecticide application (Short et al. 1982). Throughout a management program, integrated pest management (IPM) strategies are recommended because they use multiple management strategies to more economically and safely reduce pest abundance and the need for curative intervention.

\section{Intervention Cultural Control}

Proper plant maintenance through correct irrigation, fertilization, and mowing is critical to promote turfgrass health and resistance to pests. Drought stress is often associated with southern chinch bug outbreaks. However, overwatering may also contribute to additional pest problems. If the thatch layer becomes too thick, it can prevent water, fertilizer, and pesticides from moving into the soil and reaching their intended target. Thatch can be removed from a lawn by verticutting. (See "Thatch Removal" in http:// edis.ifas.ufl.edu/lh010 for more information.) Topdressing with a sand or soil mixture similar to the site's soil can also effectively reduce thatch accumulation.

Mowing is an important cultural practice for maintaining turfgrasses and promoting plant tolerance to stress. (See http://edis.ifas.ufl.edu/lh010 for cultivar- and speciesspecific St. Augustinegrass mowing recommendations.) Clippings from mowing should be left on the lawn because they break down easily, provide nutrients to the lawn, and do not contribute to thatch buildup. 
Fertilizer is commonly applied to St. Augustinegrass lawns to promote growth, density, and greenness. Fertilizers must be applied in moderation and in compliance with UF/IFAS Best Management Practices (BMPs) to conserve money and reduce potential non-target effects. (See http://edis.ifas.ufl. edu/topic_lawn_fertilization for a complete guide to fertilizing Florida turfgrasses.) Over-fertilization can increase thatch accumulation, which harbors southern chinch bug populations. Additionally, over-fertilization increases the nitrogen content within plant tissues and has been associated with increased southern chinch bug abundance in St. Augustinegrass (Busey and Snyder 1993).

One of the most effective and desirable cultural IPM strategies is using pest-resistant plants. Pest-resistant turfgrasses generally can tolerate pest feeding, are less attractive to pests, or can physically or chemically deter pests. For example, some St. Augustinegrass cultivars produce higher concentrations of oxidative enzymes in plant tissue after insect feeding, which reduces tissue damage (Rangasamy et al. 2009a). 'Captiva' St. Augustinegrass resists southern chinch bug feeding because it has heavily sclerotized cells that the insects are unable to penetrate with their mouthparts (Rangasamy et al. 2009b). Although its availability is limited, 'Captiva' is currently the only commercially available St. Augustinegrass resistant to southern chinch bug. The most widely planted cultivar of St. Augusinegrass in Florida, 'Floratam', was resistant to southern chinch bug at the time of its release in 1973. However, this resistance was overcome among Florida southern chinch bug populations within 15 years of its release (Busey and Center 1987). Pestresistant cultivars are an excellent IPM tool, but effective southern chinch bug control demands a multi-pronged approach. Chinch bugs will eventually develop the ability to feed on resistant cultivars, especially if one uses no other control methods or over-uses a single resistant cultivar.

\section{Biological Control}

Predators and parasitoids provide pest control services that reduce the need to intervene with chemical pest control measures. Several natural enemies attack southern chinch bugs in urban and suburban landscapes (Reinert 1978). One of the most common is the big-eyed bug, Geocoris spp. (Hemiptera: Geocoridae) (Figure 6), a predator that resembles the southern chinch bug, but has much larger eyes. Big-eyed bugs actively feed on southern chinch bugs. Two other predatory bug species, Xylocoris vicarius (Hemiptera: Anthocoridae) and Lasiochilus pallidulus (Hemiptera: Lasiochilidae), have been found to reduce southern chinch bug populations in turfgrass. Other generalist predators such as the striped earwig, Labidura riparia (Pallas) (Dermaptera: Labiduridae), and Sinea spp. assassin bugs (Hemiptera: Reduviidae) have been observed attacking southern chinch bugs in Florida. Sometimes the red imported fire ant, Solenopsis invicta (Hymenoptera: Formicidae), will reduce chinch bug populations, but fire ants must be present in high numbers, which is unacceptable in most lawns and presents a human health risk. There is only one known parasite of southern chinch bug, a wasp, Eumicrosoma benefica Gahan (Hymenoptera: Scelionidae), which parasitizes chinch bug eggs. This wasp is present in Florida and is often found within southern chinch bug populations in lawns (Cherry 2011).

Unfortunately, most predators and parasites of southern chinch bugs are not commercially available, and the few that are do not present an economically viable approach to managing southern chinch bugs in lawns. Predatory and parasitic insects will decline when exposed to broad spectrum insecticides like pyrethroids and carbamates (Raupp et al. 2001). Research has also found that some systemic neonicotinoids like clothianidin may reduce predatory beetle populations when applied to lawns (Larson et al. 2012). Therefore, the best way to maximize pest control benefits provided by other arthropods is by using reducedrisk insecticides (http://edis.ifas.ufl.edu/pi224) and making pesticide applications when and where they are necessary (Desneux et al. 2007). Reduced natural enemy populations have been associated with insect and mite pest outbreaks in several different plant systems.

\section{Chemical Control}

The pest control and turfgrass industries rely on insecticides to manage the southern chinch bug in Florida lawns. This is largely due to a lack of effective and easily implemented alternative IPM strategies. Many pest management professionals rely on preventive, calendar-based, coverspray applications of insecticides to ensure pest-free and vigorous lawns. As a result, both management costs and the risks associated with insecticide resistance and non-target effects on beneficial organisms are high. This is not the most economically or environmentally sustainable method for managing insect pests. A more integrated management approach is to make spot treatments to areas where chinch bugs are abundant and/or causing damage. This approach reduces non-target effects of insecticide applications and conserves products. Unfortunately, the logistics of high risk associated with spot-treating and monitoring dozens of St. Augustinegrass lawns is often unrealistic for commercial pest control professionals, which is why so many treat entire lawns. 
Insect populations become resistant to insecticides from repeated exposure to the same chemistries. Repeated exposure kills susceptible individuals and leaves resistant individuals behind to reproduce. Over time, multiple chinch bug populations have developed resistance to insecticide classes including pyrethroids, neonicotinoids, organochlorines, and organophosphates because of this repeated exposure (Wolfenbarger 1953, Kerr and Robinson 1958, Reinert 1982, Reinert and Portier 1983, Cherry and Nagata 2005, Vázquez et al. 2011). To preserve the use of insecticides we depend on, it is highly recommended to rotate insecticides with different modes of action, or insecticide resistance action committee (IRAC) numbers (Table 1). (For more, please consult http://edis.ifas.ufl. edu/in714, Managing Insecticide and Miticide Resistance in Florida Landscapes.) That way, multiple generations of chinch bugs within the same population are not exposed to the same insecticide class, and each population will be less likely to develop resistance. Therefore, future populations can be more effectively controlled with the tools we have.

Southern chinch bugs are most effectively controlled with thorough applications of systemic insecticides. Contact-toxic products may not be as effective as systemic insecticides because they depend on physical contact to work, and sufficient and uniform coverage can be difficult to achieve. In contrast, systemically active products are ingested during feeding. Another benefit of most systemic products is that they pose lower risk to natural enemies, which allows biological control to occur in between insecticide applications.

Systemic products like neonicotinoids are also preferable because they have longer residual activity inside plant tissue. Although systemic insecticides, including neonicotinoids, have been associated with pollinator toxicity and decline, this is of minimal concern if products are used properly according to the label, since St. Augustinegrass is not attractive to pollinators (Larson et al. 2017). Broadspectrum products such as pyrethroids and carbamates may initially reduce pests, but they are not active systemically. Furthermore, they provide shorter periods of control and are less compatible with natural enemies. Several combination products that contain pyrethroids and neonicotinoids (e.g., bifenthrin + imidacloprid) may provide initial high knock-down rates followed by longer systemic control. However, more work is needed to determine their longterm effects. Always follow label directions and restrictions when applying these products.

\section{References}

Addesso, K. M., H. J. McAuslane, and R. Cherry. 2012. "Aggregation Behavior of the Southern Chinch Bug (Hemiptera: Blissidae)." Environmental Entomology 41: 887-895.

Busey, P., and B. J. Center. 1987. "Southern chinch bug (Hemiptera: Heteroptera: Lygaeidae) overcomes resistance in St. Augustinegrass." Journal of Economic Entomology 80: 608-611.

Busey, P., and G. H. Snyder. 1993. "Population outbreak of the southern chinch bug is regulated by fertilization." International Turfgrass Society Research Journal 7: 353-361.

Cherry, R. 2011. "Distribution of Eumicrosoma benefica (Hymenoptera: Scelionidae) in Southern Chinch Bug (Hemiptera: Blissidae) Populations." Florida Entomologist 94: 352-353.

Cherry, R., and R. Nagata. 2005. "Development of resistance in southern chinch bugs (Hemiptera: Lygaeidae) to the insecticide bifenthrin." The Florida Entomologist 88: 219-221.

Desneux, N., A. Decourtye, and J. M. Delpuech. 2007. "The sublethal effects of pesticides on beneficial arthropods." Annual Review of Entomology 52: 81-106.

Kerr, S. H. 1966. "Biology of the lawn chinch bug, Blissus insularis." Florida Entomologist 49: 9-18.

Kerr, S. H., and F. A. Robinson. 1958. "Chinch bug control tests, 1956-57." The Florida Entomologist 41: 97-101.

Larson, J. L., C. T. Redmond, and D. A. Potter. 2012. "Comparative impact of an anthranilic diamide and other insecticidal chemistries on beneficial invertebrates and ecosystem services in turfgrass." Pest Management Science 68: 740-748.

Larson, J. L., A. Dale, D. Held, B. McGraw, D. S. Richmond, K. Wickings, and R. Chris Williamson. 2017. "Optimizing Pest Management Practices to Conserve Pollinators in Turf Landscapes: Current Practices and Future Research Needs." Journal of Integrated Pest Management 8.

Rangasamy, M., B. Rathinasabapathi, H. J. McAuslane, R. H. Cherry, and R. T. Nagata. 2009a. "Oxidative responses of St. Augustinegrasses to feeding of southern chinch bug, Blissus insularis Barber." Journal of Chemical Ecology 35: 796-805. 
Rangasamy, M., B. Rathinasabapathi, H. J. McAuslane, R. Cherry, and R. Nagata. 2009b. "Role of leaf sheath lignification and anatomy in resistance against southern chinch bug (Hemiptera: Blissidae) in St. Augustinegrass." Journal of Economic Entomology 102: 432-439.

Raupp, M. J., J. J. Holmes, C. Sadof, P. M. Shrewsbury, and J. A. Davidson. 2001. "Effects of cover sprays and residual pesticides on scale insects and natural enemies in urban forests." Journal of Arboriculture 27: 203-214.

Reinert, J. A. 1978. "Natural enemy complex of the southern chinch bug in Florida." Annals of the Entomological Society of America 71: 728-731.

Reinert, J. A. 1982. "Carbamate and synthetic pyrethroid insecticides for control of organophosphate-resistant southern chinch bugs (Heteroptera: Lygaeidae)." Journal of Economic Entomology 75.

Reinert, J. A., and K. M. Portier. 1983. "Distribution and characterization of organophosphate-resistant southern chinch bugs (Heteroptera: Lygaeidae) in Florida." Journal of Economic Entomology 76: 1187-1190.

Satterthwaite, L. N., A. W. Hodges, J. J. Haydu, and J. L. Cisar. 2009. "An agronomic and economic profile of Florida's sod industry in 2007." Florida Agricultural Experiment Station, Florida Cooperative Extension Service.

Vasquez, J. C., and E. A. Buss. 2006. "Southern chinch bug feeding impact on St. Augustinegrass growth under different irrigation regimes." Applied Turfgrass Science. doi:10.1094/ATS-2006-0711-01-RS.

Vázquez, C., R. N. Royalty, and E. A. Buss. 2011. "Susceptibility of Blissus insularis (Heteroptera: Hemiptera: Blissidae) Populations in Florida to Bifenthrin and Permethrin." Florida Entomologist 94: 571-581.

Wolfenbarger, D. O. 1953. "Insect and mite control problems in lawn and golf courses." The Florida Entomologist 36: 9-12. 
Table 1. Insecticides available for southern chinch bug control in Florida.

\begin{tabular}{|c|c|c|c|c|c|}
\hline Active Ingredient & Trade Name(s) & Chemical Class & IRAC Class & $\begin{array}{l}\text { Labeled } \\
\text { Application Site }\end{array}$ & Reduced-risk \\
\hline Acephate & Orthene & Organophosphate & 1B & $\mathrm{GC}, \mathrm{S}$ & No \\
\hline Azadirachtin & Azatin, Azaguard & Azadirachtin & $18 \mathrm{~B}$ & $\mathrm{GC}, \mathrm{S}, \mathrm{L}$ & - \\
\hline Bifenthrin & Talstar, Menace & Pyrethroid & 3 & $\mathrm{GC}, \mathrm{S}, \mathrm{L}$ & No \\
\hline Carbaryl & Sevin & Carbamate & $1 \mathrm{~A}$ & GC, S, L & No \\
\hline Clothianidin & Arena & Neonicotinoid & $4 \mathrm{~A}$ & GC, S, L & No \\
\hline Clothianidin + Bifenthrin & Aloft & Neonicotinoid + Pyrethroid & $4 A, 3$ & $\mathrm{~L}$ & No \\
\hline${ }^{*}$ Chlorantraniliprole & Acelepryn & Anthranilic diamide & 28 & GC, S, L & Yes \\
\hline${ }^{*}$ Cyantraniliprole & Mainspring & Anthranilic diamide & 28 & GC, S, L & Yes \\
\hline Deltamethrin & Deltagard & Pyrethroid & 3 & GC, L & No \\
\hline${ }^{*}$ Dinotefuran & Zylam & Neonicotinoid & $4 \mathrm{~A}$ & GC, S, L & No \\
\hline Horticultural oil & Many & - & - & $\mathrm{GC}, \mathrm{S}, \mathrm{L}$ & - \\
\hline Imidacloprid & Merit & Neonicotinoid & $4 \mathrm{~A}$ & $\mathrm{GC}, \mathrm{S}, \mathrm{L}$ & No \\
\hline Insecticidal soap & Many & - & - & $\mathrm{GC}, \mathrm{S}, \mathrm{L}$ & - \\
\hline Thiamethoxam & Meridian & Neonicotinoid & $4 \mathrm{~A}$ & GC, S, L & No \\
\hline $\begin{array}{l}\text { Zeta-cypermethrin }+ \\
\text { Bifenthrin }+ \text { Imidacloprid }\end{array}$ & $\begin{array}{l}\text { Triple Crown T\&O, } \\
\text { Golf }\end{array}$ & Pyrethroid + Neonicotinoid & $3,4 \mathrm{~A}$ & GC, L & No \\
\hline \multicolumn{6}{|c|}{$\begin{array}{l}\text { *Suppression of southern chinch bug populations } \\
\text { - Application sites: golf course (GC), sod farm (S), landscape (L) } \\
\text { - Trade names used are not comprehensive and do not imply endorsement of products. }\end{array}$} \\
\hline
\end{tabular}

